\title{
PHENOTYPIC CORRELATION AND PATH ANALYSIS IN CULTIVARS AND STRAINS OF UPLAND RICE FOR DROUGHT TOLERANCE
}

\author{
CORRELAÇÃO FENOTÍPICA E ANÁLISE DE TRILHA EM CULTIVARES E \\ LINHAGENS DE ARROZ DE SEQUEIRO PARA TOLERÂNCIA À SECA
}

\author{
Thiago Gledson Rios TERRA ${ }^{1}$; Tarcísio Castro Alves de Barros LEAL ${ }^{1}$; \\ Paulo Hideo Nakano RANGEL ${ }^{2}$; Aluízio Borém ${ }^{3}$ \\ 1. Universidade Federal do Tocantins, Gurupi, TO, Brasil. tgterra@uft.edu.br; 2. Embrapa Arroz e Feijão, Santo Antônio de Goiás, GO, \\ Brasil; 3. Universidade Federal de Viçosa, Viçosa, MG, Brasil
}

\begin{abstract}
The purpose of this study was to estimate the phenotypic correlations between 14 traits obtained in a thematic core collection of upland rice for drought tolerance and partition them into direct and indirect effects by path analysis. Two experiments were carried out (with and without water stress). One hundred samples were evaluated in a triple 10x10 lattice design. The plot was formed by four rows, 3.0 metres long, spaced at $0.35 \mathrm{~m}$. The plot useful area was constituted by two central rows of $2.0 \mathrm{~m}$ in length, totalling $1.4 \mathrm{~m}^{2}$, where data from 14 traits were collected, five from the root system and nine from the aerial part of the plant. Of the evaluated traits, spikelet sterility was the main grain yield determinant, presenting relevant negative correlations of -0.77 and -0.59 in environments with and without drought stress, respectively. The partitioning of spikelet sterility correlations presented negative direct effects on grain yield in environments with (-0.60) and without (-0.62) water stress, corroborating the negative correlations between these traits. The obtained data confirmed that spikelet sterility is an important variable for the selection of rice strain submitted to water deficit. Partial correlation coefficients indicated that only $70.33 \%$ in the environment with stress and $50.30 \%$ in the environment without stress of grain yield variation were phenotypically explained by variables considered in path analysis, thereby showing the complexity of the selection for drought-tolerant rice.
\end{abstract}

KEYWORDS: Upland rice. Characters. Roots. Drought tolerance

\section{INTRODUCTION}

Rice is one of the main cereals cultivated in the world and its evolution process led it to adapt to the most varied soil and climate conditions. Planting conditions vary from flooded environments, such as in the case of flooded rice systems, where, in general, varieties of the indica subtype are used, to dry environments (upland rice). The water necessary for plant growth and development in the upland system depends on the rainfall regime, and this system is therefore vulnerable to drought stress. In this latter cultivation system, varieties of the japonica subtype are used (ABADIE et al., 2005).

The stress caused by water deficit has long caused yield reduction in several crops, and this has recently been aggravated due to climate changes. Under this type of stress, the plant generally shows an increase in diffusive resistance to water vapour, thanks to stomatal closure, a reduction in transpiration and carbon dioxide supply for the photosynthetic process, reduced cellular growth and increased photorespiration (SHINOZAKI; YAMAGUCHI-SHINOZAKI, 2007), thereby reducing the photosynthesis rate and, consequently, having undesirable effects on vigour and plant height, pollen grain fertility and yield (BOTA et al.,
2004). For Nguyen et al. (1997), drought resistance physiologic mechanisms in rice cultivation are related to moderate water use by the plant, leaf area reduction, leaf water loss control and root ability in exploring deeper soil layers. An improvement in yield stability in environments with water deficit is essential for this cultivation, and can be carried out by identifying the traits that may contribute to drought resistance (BABU et al., 2003).

The development of water stress-tolerant upland rice cultivars by breeding is recognized as the most efficient strategy to relieve food insecurity caused by water shortage (HUANG et al., 2007). However, little success has been achieved so far in developing water stress-tolerant cultivars due to this characteristic having a quantitative heritage and strong environmental influence (SHINOZAKI; YAMAGUCHI-SHINOZAKI, 2007).

Traits controlled by several genes, with low heritability and great interaction with the environment, can be difficult to measure, and, therefore, have low efficiency upon selection. One of the alternatives to increase gains by selection in a low-heritage characteristic would be to select another characteristic of high heritage, easy mensuration and strong correlation (LAFITTE et al., 2003). The two causes of genetic correlation 
between two traits are pleiotropy and genic connection. The correlation caused by pleiotropy is when two characters are influenced by the same genes (KUREK et al., 2001), which are of great importance in breeding programmes (MARCHEZAN et al., 2005). However, this simple correlation may induce mistakes in the relation between two variables, as there may be an effect of a third variable acting on the expression of the main variable. To overcome this problem, WRIGHT (1921) proposed partitioning the correlations between characters into direct and indirect effects, using path analysis (CRUZ et al., 2004). Path analysis is a standardized partial regression coefficient that allows the correlation coefficient to be partitioned into direct and indirect effects and the action of specific components that produce a certain correlation between variables to be studied.

Understanding the relations between the traits that influence water stress resistance is of vital importance for genetic improvement programmes aimed at developing upland rice cultivars tolerance to this abiotic stress (ABREU et al., 2016). Thus, the purpose of the present study was to estimate the phenotypic correlations between 14 traits obtained in a thematic core collection of upland rice for drought resistance and to partition them into direct and indirect effects by path analysis.

\section{MATERIAL AND METHODS}

Two experiments (with and without water stress) were carried out between June and November 2007 in the Experimental Unit of the Federal University of Tocantins (UFT), at the University Campus of Gurupi, TO, Brazil, situated at a latitude of $11.7458{ }^{\circ}$ south, a longitude of $49.0497^{\circ}$ west and an altitude of $280 \mathrm{~m}$. In this region, a well-defined period without rainfall occurs, from May to September, which represents a favourable environment for studies on drought resistance. The rainfall from June to October was practically nil, beginning in the second half of October with low intensity (Figure 1). Maximum and minimum temperatures were approximately 35 ${ }^{\circ} \mathrm{C}$ and $15^{\circ} \mathrm{C}$, respectively, from June to August and $20{ }^{\circ} \mathrm{C}$ from September to November. The relative air moisture in this period varied from very low values of approximately $10 \%$ to the highest value of $90 \%$.

The soil where the experiments were carried out is characterized as a dystrophic yellow latosol with a sandy texture. Starter and top dressing fertilization, as well as weed, pest and disease control, were carried out according to technical recommendations for upland rice farming.

Both experiments (with and without water stress) were equally irrigated up to 35 days after emergence (DAE), using an irrigation system formed by a self-propelled set and wheeled vehicle with side bars and regulating pressure valves at the end of spraying tips, to obtain a constant and homogeneous water sheet during application. After this period, for the stress treatment, approximately half of the water sheet was supplied, considering that the soil water tension used in the experiment for the environment without drought stress was $250 \mathrm{mb}$, as suggested by Stone et al. (1986). Irrigation shift was adjusted according to crop evapotranspiration, using tensiometers placed in strategic areas, with the porous capsule at a depth of $0.15 \mathrm{~m}$ in the soil.

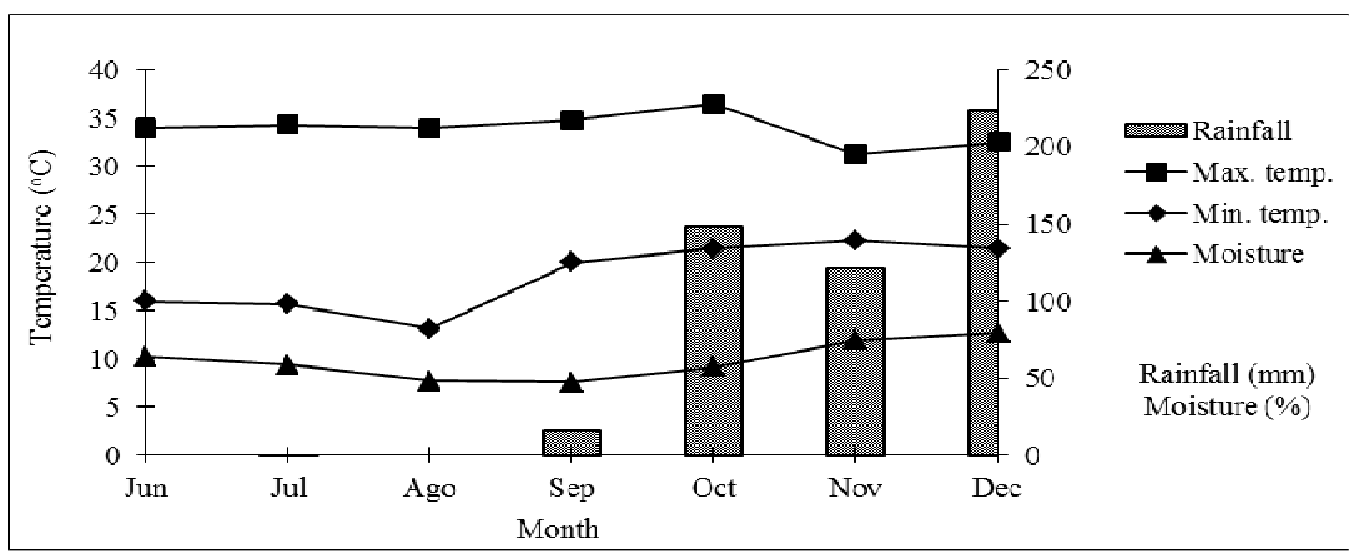

Figure 1. Maximum (max. temp.) and minimum (min. temp.) temperatures in ${ }^{\circ} \mathrm{C}$, relative air moisture (\%) and rainfall (mm) from June to December 2007, in Gurupi city (TO, Brazil). Source: INMET, 2008.

One hundred samples were evaluated, all of the japonica subtype, with 86 traditional rice varieties from the Thematic Core Collection of
Upland Rice for Drought Tolerance (TERRA et al., 2015) and 14 cultivars and elite strains from the programme for genetic improvement of Embrapa 
Rice and Beans in a 10x10 triple lattice experimental delineation. The plot comprised four rows, 3.0 metres long, spaced at 0.35 metres. The plot useful area was constituted by two central rows of 2.0 metres in length, totalling $1.4 \mathrm{~m}^{2}$. At 25 days after stress beginning in the environment with water deficit, evaluations began in both experiments.

The following data were collected:

a) Leaf canopy temperature (LCT), obtained from two samples per plot in each measurement, totalling five readings per treatment. Evaluations were carried out using a laser thermometer (Raytek Raynger ST), placed at $10 \mathrm{~cm}$ of leaf canopy, always on the day prior to irrigation, at the hottest time of the day (between 12:30 $\mathrm{h}$ and 14:00 h), with a more elevated level of soil water tension, in both treatments (with and without stress);

b) Flowering average (FLO), number of days from planting to $50 \%$ tillers with panicles;

c) Plant height $(\mathrm{H})$, obtained at harvesting from 10 competitive plants in the useful plot area;

d) Number of tillers (TL);

e) Percentage of tiller sterility (TS), obtained by counting the number of tillers and panicles in a linear metre, and the number and percentage of tillers without panicles verified;

f) Number of filled grains per panicle (GPP);

g) Percentage of spikelet sterility (PSS) per panicle;

h) 100-grain weight (GW), obtained from a sample of 10 panicles by plot by counting the number of full and empty grains;

i) The percentage of spikelet sterility is considered a primary component of production (ALVAREZ et al., 2012) and was obtained using the following formula: $\mathrm{PSS}=(\mathrm{EG} \times 100) / \mathrm{TS}$; where: $\mathrm{EG}=$ number of empty grains; TS = total number of spikelets per panicle;

j) Grain yield in $1.4 \mathrm{~m}^{2}(\mathrm{Y})$ of evaluated genotypes was obtained from the harvest of grains from two central rows from each plot, discarding $0.5 \mathrm{~m}$ from the end of each row, totalling a useful harvest area of $1.4 \mathrm{~m}^{2}$;

k) Root data, collected at early flowering in each plot. For this, soil and root samples were collected at depths of 20 to $60 \mathrm{~cm}$, using a drill with a $7 \mathrm{~cm}$ internal diameter. These samples were removed at a distance of approximately $7 \mathrm{~cm}$ from one of the two central rows. The first $20 \mathrm{~cm}$ were discarded. The soil and root samples were washed in water and sieved in $1 \mathrm{~mm}$ sieves, separating the roots. Then the samples were placed in plastic bags, properly identified and stored in a freezer. Root measurement and qualification was carried out using WinRHIZO (Regent Instruments Canada INC, 2008) Pro v 2008a, 32-bit software. For that, root samples were thawed and placed in acrylic tray with a water line/sheet of 2 to $3 \mathrm{~mm}$, and then scanned. Images were stored in TIFF format. The root variables estimated by the WinRHIZO software were: root length (RL), contact surface (CS), mean root diameter (MRD), volume (V) and number of root branches (RB).

Phenotypic correlation coefficients were estimated by variance and covariance components, according to the method suggested by Kempthorne (1973), Mather (1966), and Mode and Robinson (1959). The significance of the correlation coefficients was evaluated by t-test at $1 \%$ and $5 \%$ probability.

Phenotypic correlation coefficients were partitioned into direct and indirect effects using the method of path coefficients, showing correlations for grain yield (Y) in $1.4 \mathrm{~m}^{2}$ as the main variable, and FLO, H, GPP, PSS, GW, TL and TS, LCT, RL, $\mathrm{CS}, \mathrm{MRD}, \mathrm{V}$ and RB as explanatory variables.

The analyses of data were carried out using the Genes version 2013 5.0.1 software program for statistical analyses (CRUZ, 2013).

\section{RESULTS AND DISCUSSION}

\section{Phenotypic correlations}

Table 1 shows estimates of phenotypic correlations between all evaluated variables for two farming conditions, with and without water stress. Significant differences were observed at $1 \%$ and $5 \%$ probability by t-test for several phenotypic correlation coefficients.

Negative correlations were obtained between the variables $\mathrm{Y}$ and PSS of -0.77 and -0.59 in environments with and without stress, respectively. This shows that spikelet sterility in panicles is the main determinant of grain yield. Similar results were obtained by LAFITTE et al. (2003) and KUMAR et al. (2008). These authors showed that due to higher PSS inheritance, it could provide higher selection gains.

In the condition of water stress, the variable $\mathrm{Y}$ was positively correlated with the variables $\mathrm{H}$ $\left(0.31^{* *}\right)$, GPP $(0.27 * *)$ and GW $\left(0.45^{* *}\right)$. The same variable was negatively correlated with TL ($\left.0.33^{* *}\right)$. Conversely, in the condition without stress, $\mathrm{Y}$ presented a positive and significant correlation only with $\mathrm{GW}\left(0.35^{* *}\right)$ and a negative and significant correlation with the variables FLO ($0.31 * *)$ and $\mathrm{H}(-0.21 * *)$. $\mathrm{Y}$ was positively correlated with $\mathrm{H}\left(0.31^{* *}\right)$ in the condition with stress and negatively $(-0.21 *)$ in the condition without stress. 
Table 1. Phenotypic correlation between the variables grain yield (Y), days to flowering (FLO), plant height (H), grains per panicle (GPP), spikelet sterility (PSS), weight per hundred grains (GW), number of tillers (TL), tiller sterility (TS), leaf canopy temperature (LCT), root length (RL), root contact surface (CS), mean root diameter (MRD), root volume (V) and number of branches (RB). Upper table part shows condition with drought stress and bottom part shows condition without drought stress in a core collection of upland rice. UFT, Gurupi - TO, Brazil. 2007.

\begin{tabular}{|c|c|c|c|c|c|c|c|c|c|c|c|c|c|c|c|}
\hline & & $\mathrm{Y}$ & FLO & $\mathrm{H}$ & GPP & PSS & GW & TL & $\mathrm{TS}$ & LCT & RL & $\mathrm{CS}$ & MRD & V & $\mathrm{RB}$ \\
\hline \multirow{14}{*}{ 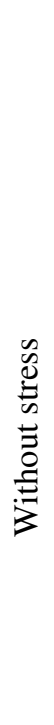 } & $\mathrm{Y}$ & -- & 0.0741 & $0.313 * *$ & $0.2748 * *$ & $-0.7715^{* *}$ & $0.4555^{* *}$ & $-0.3258 * *$ & -0.0631 & -0.1461 & 0.1219 & 0.1138 & 0.0853 & 0.0678 & 0.0019 \\
\hline & FLO & $-0.3084 * *$ & -- & $0.6722 * *$ & $0.5395 * *$ & 0.0129 & $-0.4224 * *$ & $-0.3601 * *$ & 0.0319 & 0.1568 & $0.3302 * *$ & $0.2834 * *$ & 0.0303 & $0.2187^{*}$ & 0.1785 \\
\hline & $\mathrm{H}$ & $-0.2144 *$ & $0.7613 * *$ & -- & $0.5692 * *$ & -0.192 & 0.0401 & $-0.4867 * *$ & 0.0094 & 0.0146 & $0.2755^{* *}$ & $0.2562 * *$ & 0.0277 & $0.2118^{*}$ & 0.0549 \\
\hline & GPP & -0.0745 & $0.3043 * *$ & $0.3239 * *$ & -- & -0.1475 & $-0.2501 *$ & $-0.3592 * *$ & -0.0349 & -0.1108 & $0.2924 * *$ & $0.2753 * *$ & 0.0877 & $0.2214^{*}$ & -0.0202 \\
\hline & PSS & $-0.5953 * *$ & 0.1818 & 0.1147 & 0.141 & -- & $-0.5083 * *$ & $0.3078 * *$ & 0.0509 & 0.0837 & 0.0124 & -0.0003 & -0.0146 & 0.0117 & 0.0683 \\
\hline & GW & $0.3513 * *$ & $-0.6175^{* *}$ & $-0.363 * *$ & $-0.4379 * *$ & $-0.4167 * *$ & -- & -0.1758 & 0.0251 & -0.0811 & -0.0682 & -0.075 & -0.1037 & -0.0826 & -0.0354 \\
\hline & $\mathrm{TL}$ & -0.0069 & -0.0923 & $-0.2946^{* *}$ & $-0.3355^{* *}$ & 0.098 & -0.0082 & -- & 0.0058 & 0.0606 & -0.0866 & -0.0291 & 0.1364 & 0.019 & -0.0896 \\
\hline & $\mathrm{TS}$ & 0.0707 & -0.0799 & -0.1336 & -0.0136 & $-0.2707 * *$ & 0.1454 & 0.1583 & -- & -0.0435 & -0.0254 & -0.0718 & -0.0813 & -0.0913 & 0.1165 \\
\hline & LCT & -0.1302 & -0.058 & -0.0289 & -0.1286 & 0.1202 & -0.0226 & 0.043 & -0.0001 & -- & 0.1528 & $0.2133^{*}$ & 0.0462 & $0.2419 *$ & -0.0014 \\
\hline & RL & 0.1641 & $0.301 * *$ & $0.5228 * *$ & $0.239^{*}$ & -0.1689 & -0.1087 & $-0.207 *$ & -0.061 & -0.1635 & -- & $0.8963 * *$ & $0.2384 *$ & $0.7116^{* *}$ & $0.3106^{* *}$ \\
\hline & CS & 0.1088 & $0.3062 * *$ & $0.5102 * *$ & $0.2867 * *$ & -0.0827 & -0.1412 & $-0.2112^{*}$ & -0.0783 & -0.1851 & $0.9528 * *$ & -- & $0.5726 * *$ & $0.9457 * *$ & -0.0863 \\
\hline & MRD & 0.1242 & 0.1807 & $0.2706 * *$ & $0.197 *$ & 0.1085 & -0.0913 & -0.0431 & -0.0864 & $-0.233 *$ & $0.5775 * *$ & $0.705 * *$ & -- & $0.7352 * *$ & $-0.7332 * *$ \\
\hline & $\mathrm{V}$ & 0.0575 & $0.2862 * *$ & $0.4622 * *$ & $0.2925^{* *}$ & -0.0092 & -0.1711 & -0.1912 & -0.0958 & $-0.212^{*}$ & $0.8621 * *$ & $0.9622 * *$ & $0.764 * *$ & -- & $-0.3516^{* *}$ \\
\hline & $\mathrm{RB}$ & 0.0777 & $0.2693 * *$ & $0.4968 * *$ & $0.2359 *$ & $-0.2111 *$ & -0.1133 & -0.0872 & -0.0562 & -0.0303 & $0.8364 * *$ & $0.7861 * *$ & $0.3009 * *$ & $0.6761 * *$ & -- \\
\hline
\end{tabular}

** and *, significant at $1 \%$ and $5 \%$ probability, respectively, by t-test. 
The results show a tendency of higher plants to present higher drought resistance. This may be due to the fact that plants with this morphology present a greater root volume in deeper soil layers, and consequently can explore wetter areas. In the definition of a plant ideotype for upland rice conditions, this characteristic needs to be considered, prioritizing higher plants.

FLO presented, in conditions with and without stress, positive and significant correlations with the variable $\mathrm{H}(0.67 * *$ and $0.76 * *$, respectively). These correlations might create some difficulty in obtaining more precocious varieties (average flowering around 70 days) and higher plants when using a direct planting system, where upland rice is the second option after soy. Lafitte et al. (2003) reported that the number of days till flowering is a trait that can be used to differentiate genotypes with different responses to drought stress, and that the difference between flowerings may vary from 12 days before to 7 days after, when compared with the condition without stress.

The $\mathrm{H}$ variable presented positive and significant correlations with GPP $\left(0.57^{* *}\right.$ and $0.32 * *$ with and without stress, respectively) in two cultivation conditions, showing that higher plants, in general, have larger panicles and more grains.

Leaf canopy temperature (LCT) was not correlated with any traits of the aerial part evaluated in both environments in the present study. This shows that this variable is of little use as one of the determining drought resistance parameters in the evaluated population.

As for root parameters (RL, CS, MRD and V), correlations with aerial part variables in the environment with stress were small, even those that presented $1 \%$ and $5 \%$ significance by t-test. Root data collection in the field or even in controlled conditions is a laborious process and in some cases it is not completely accurate, due to the methodologies used, soil separation process or root quantification. This may in part explain the decreased magnitudes of correlations with the aerial plant part. In the environment without stress, the most elevated observed correlations were between RL x H $(0.5228 * *)$ and CS x H $(0.5102$ $* *)$, indicating that higher plants can present a greater length and root contact surface with the soil.

In general, the correlations between root variables were elevated and highly significant, which was expected, since the evaluated root traits are not independent.
Tables 2 and 3 show the results for phenotypic correlation coefficients for traits FLO, H, GPP, PSS, GW, TL, TS, LCT, RL, CS, MRD, V and $\mathrm{RB}$ with grain yield in $1.4 \mathrm{~m}^{2}$.

According to Jagadish et al. (2007), spikelet sterility is a variable of great importance among the production primary components in rice farming and it is greatly affected by abiotic factors such as temperature and moisture. In this study, PSS presented negative direct effects on grain yield in environments with (-0.6051) and without (-0.62) stress, thereby corroborating the negative correlations between these traits (Table 2). PSS was the most important variable in the determination of grain yield in the evaluated genotype population. Jongdee et al. (2006) also emphasized that spikelet sterility is an important variable for the selection of rice strain submitted to water deficit.

In general, the direct and indirect effects of the traits FLO, H, GPP, GW, TL and TS were small, showing little influence of these variables on grain yield and corroborating the low estimate values obtained for phenotypic correlations.

The non-significant phenotypic correlations between leaf canopy temperature (LCT) and the evaluated traits (Table 1) are explained by the direct and indirect effects of low significance (Table 3), showing little importance of this variable in the selection of more drought-tolerant genotypes in the evaluated population.

In the environment with stress, root length and volume presented negative direct effects of 0.6741 and -0.7851 , respectively, for grain yield. However, these effects were neutralized by elevated positive indirect effects of 1.0706 and 1.1294, respectively, for root surface (Table 3).

\section{Path analysis}


Table 2. Path analysis of the variables days to flowering (FLO), plant height (H), grains per panicle (GPP), spikelet sterility (PSS), weight per hundred grains (GW), number of tillers (TL) and tiller sterility (TS) regarding the variable grain yield (Y), in a core collection of upland rice under normal irrigation condition (NS) and under drought stress (WS). UFT, Gurupi (TO, Brazil). 2007.

\begin{tabular}{|c|c|c|c|c|c|c|c|c|c|c|c|c|c|c|}
\hline & FLO & & $\mathrm{H}$ & & GPP & & PSS & & GW & & $\mathrm{TL}$ & & $\mathrm{TS}$ & \\
\hline Effect & WS & NS & WS & NS & $\mathrm{WS}$ & NS & WS & NS & $\mathrm{WS}$ & NS & WS & NS & $\mathrm{WS}$ & NS \\
\hline Direct on $\mathrm{Y}$ & -0.0310 & -0.2541 & 0.0986 & -0.0160 & 0.1968 & 0.1180 & -0.6051 & -0.6200 & 0.2152 & -0.0114 & -0.0225 & 0.1130 & -0.0504 & -0.1294 \\
\hline \multicolumn{15}{|l|}{ Indirect via: } \\
\hline Flowering & -- & -- & -0.0209 & -0.1932 & -0.0167 & -0.0773 & -0.0004 & -0.0457 & 0.0130 & 0.1570 & 0.0112 & 0.0230 & -0.0009 & 0.0201 \\
\hline Height & 0.0665 & -0.0122 & -- & -- & 0.0560 & -0.0052 & -0.0188 & -0.0019 & 0.0038 & 0.0058 & -0.0481 & 0.0047 & 0.0009 & 0.0021 \\
\hline Grains/panicle & 0.1063 & 0.0359 & 0.1117 & 0.0383 & -- & -- & -0.0289 & 0.0168 & -0.0495 & -0.0517 & -0.0705 & -0.0398 & -0.0070 & -0.0020 \\
\hline Spikelet ster. & -0.0083 & -0.1116 & 0.1156 & -0.0718 & 0.0890 & -0.0882 & -- & -- & 0.3076 & 0.2583 & -0.1861 & -0.0612 & -0.0308 & 0.1678 \\
\hline Weight/100 grains & -0.0905 & 0.0070 & 0.0084 & 0.0041 & -0.0541 & 0.0050 & -0.1094 & 0.0047 & -- & -- & -0.0381 & 0.0001 & 0.0054 & -0.0017 \\
\hline Tiller number & 0.0081 & -0.0102 & 0.0110 & -0.0333 & 0.0081 & -0.0381 & -0.0069 & 0.0112 & 0.0040 & -0.0008 & -- & -- & -0.0001 & 0.0179 \\
\hline Tiller sterility & -0.0015 & 0.0102 & -0.0005 & 0.0173 & 0.0018 & 0.0022 & -0.0026 & 0.0350 & -0.0013 & -0.0188 & -0.0003 & -0.0205 & -- & -- \\
\hline Temperature & -0.0069 & 0.0000 & -0.0007 & 0.0000 & 0.0050 & 0.0000 & -0.0038 & 0.0000 & 0.0020 & 0.0000 & -0.0028 & 0.0000 & 0.0037 & 0.0000 \\
\hline Root length & -0.2227 & 0.1216 & -0.1844 & 0.2124 & -0.1979 & 0.0978 & -0.0083 & -0.0686 & 0.0459 & -0.0442 & 0.0586 & -0.0841 & 0.0171 & -0.0248 \\
\hline Root surface & 0.3365 & 0.0662 & 0.3036 & 0.1111 & 0.3294 & 0.0627 & -0.0004 & -0.0180 & -0.0896 & -0.0307 & -0.0345 & -0.0460 & -0.0857 & -0.0170 \\
\hline Mean root diameter & 0.0116 & 0.0477 & 0.0120 & 0.0728 & 0.0394 & 0.0528 & -0.0064 & 0.0291 & -0.0458 & -0.0244 & 0.0606 & -0.0117 & -0.0359 & -0.0231 \\
\hline Root volume & -0.1697 & -0.1350 & -0.1649 & -0.2201 & -0.1737 & -0.1395 & -0.0092 & 0.0044 & 0.0648 & 0.0812 & -0.0152 & 0.0911 & 0.0717 & 0.0454 \\
\hline Root branch number & 0.0762 & -0.0736 & 0.0228 & -0.1358 & -0.0089 & -0.0648 & 0.0286 & 0.0578 & -0.0148 & 0.0310 & -0.0380 & 0.0238 & 0.0489 & 0.0154 \\
\hline Total & $0.0741^{\mathrm{ns}}$ & $-0.3084 * *$ & $0.313 * *$ & $-0.2144 *$ & $0.2748 * *$ & $-0.3513 * *$ & $-0.7715 * *$ & $-0.5953 * *$ & $0.4555 * *$ & $0.3513 * *$ & $-0.3258 * *$ & $-0.0069^{\mathrm{ns}}$ & $-0.063^{\mathrm{ns}}$ & $0.071^{\mathrm{ns}}$ \\
\hline
\end{tabular}

Coefficient of determination: WS:0.7033; NS: 0.5030

Effect of residual variable: WS:0.5447; NS: 0.7050

**,* and ${ }^{\mathrm{ns}}$ significant at $1 \%$ and $5 \%$ probability and non-significant, respectively, by t-test. 


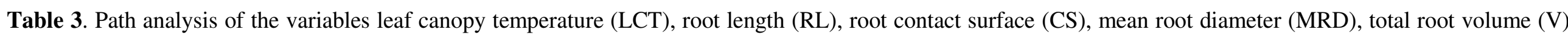
and number of root crutches (RB) on the variable grain yield (Y), in a core collection of upland rice under normal irrigation condition (NS) and under drought stress (WS). UFT, Gurupi (TO, Brazil). 2007.

\begin{tabular}{|c|c|c|c|c|c|c|c|c|c|c|c|c|}
\hline & LCT & & RL & & $\mathrm{CS}$ & & MRD & & $\mathrm{V}$ & & $\mathrm{RB}$ & \\
\hline Effect & WS & NS & WS & NS & WS & NS & WS & NS & WS & NS & WS & NS \\
\hline Direct on yield & -0.0452 & -0.0001 & -0.6741 & 0.4062 & 1.1943 & 0.2176 & 0.4420 & 0.2676 & -0.7851 & -0.4748 & 0.4195 & -0.2737 \\
\hline \multicolumn{13}{|l|}{ Indirect via: } \\
\hline Flowering & -0.0047 & 0.0146 & -0.0102 & -0.0761 & -0.0087 & -0.0773 & -0.0008 & -0.0453 & -0.0067 & -0.0722 & -0.0056 & -0.0684 \\
\hline Height & 0.0015 & 0.0005 & 0.0270 & -0.0084 & 0.0251 & -0.0082 & 0.0027 & -0.0044 & 0.0207 & -0.0074 & 0.0054 & -0.0079 \\
\hline Grains/panicle & -0.0219 & -0.0153 & 0.0578 & 0.0284 & 0.0543 & 0.0340 & 0.0175 & 0.0233 & 0.0436 & 0.0347 & -0.0042 & 0.0280 \\
\hline Spikelet sterility & -0.0505 & -0.0745 & -0.0074 & 0.1046 & 0.0002 & 0.0513 & 0.0088 & -0.0673 & -0.0071 & 0.0057 & -0.0413 & 0.1308 \\
\hline Weight/100 grains & -0.0094 & 0.0003 & -0.0147 & 0.0012 & -0.0161 & 0.0016 & -0.0223 & 0.0010 & -0.0178 & 0.0019 & -0.0076 & 0.0013 \\
\hline Tiller number & -0.0014 & 0.0048 & 0.0020 & -0.0234 & 0.0006 & -0.0239 & -0.0031 & -0.0049 & -0.0004 & -0.0217 & 0.0020 & -0.0098 \\
\hline Tiller sterility & 0.0041 & 0.0000 & 0.0013 & 0.0079 & 0.0036 & 0.0101 & 0.0041 & 0.0112 & 0.0046 & 0.0124 & -0.0059 & 0.0073 \\
\hline Temperature & -- & -- & -0.0069 & 0.0000 & -0.0097 & 0.0000 & -0.0021 & 0.0000 & -0.0109 & 0.0000 & 0.0001 & 0.0000 \\
\hline Root length & -0.1031 & -0.0664 & -- & -- & -0.6043 & 0.3870 & -0.1607 & 0.2345 & -0.4797 & 0.3501 & -0.2094 & 0.3397 \\
\hline Roor surface & 0.2551 & -0.0403 & 1.0706 & 0.2073 & -- & -- & 0.6838 & 0.1534 & 1.1294 & 0.2093 & -0.1031 & 0.1710 \\
\hline Mean root diameter & 0.0208 & -0.0624 & 0.1054 & 0.1545 & 0.2531 & 0.1886 & -- & -- & 0.3249 & 0.2044 & -0.3240 & 0.0805 \\
\hline Root volume & -0.1902 & 0.1005 & -0.5587 & -0.4093 & -0.7425 & -0.4568 & -0.5772 & -0.3627 & -- & -- & 0.2760 & -0.3210 \\
\hline Root branch number & -0.0008 & 0.0083 & 0.1303 & -0.2289 & -0.0362 & -0.2152 & -0.3076 & -0.0824 & -0.1475 & -0.1851 & -- & -- \\
\hline Total & $-0.1461^{\mathrm{ns}}$ & $-0.1302^{\mathrm{ns}}$ & $0.1219^{\mathrm{ns}}$ & $0.1641^{\mathrm{ns}}$ & $0.1138^{\mathrm{ns}}$ & $0.1088^{\mathrm{ns}}$ & $0.0853^{\mathrm{ns}}$ & $0.1242^{\mathrm{ns}}$ & $0.0678^{\mathrm{ns}}$ & $0.0575^{\mathrm{ns}}$ & $0.0019^{\mathrm{ns}}$ & $0.0777^{\mathrm{ns}}$ \\
\hline
\end{tabular}

Coefficient of determination: WS:0.7033; NS: 0.5030

Effect of residual variable: WS:0.5447; NS: 0.7050

${ }^{\mathrm{n} s}$ non-significant by t-test. 
With regard to the root traits, the root contact surface (CS) in the environment with stress (Table 3) was the variable with the highest positive influence on grain yield, indicating that accesses with greater root contact surface with the soil would have a higher water absorption capacity. However, this direct effect (1.1943) was counterbalanced in part by the negative indirect effect for root volume $(-0.7425)$.

The coefficients of partial determinations indicated that only $70.33 \%$ in the environment with stress and $50.30 \%$ in the environment without stress of the grain yield variation were explained, phenotypically, by variables considered in the path analysis. This shows the complexity of the selection for drought-tolerant rice, corroborated by the residual variation effect of $54.47 \%$ and $70.50 \%$ in the environments with and without water stress, respectively. The Experimental Field of the Federal
University of Tocantins (Gurupi, TO, Brazil) is located in a region where a dry period occurs from May to September, when the experimental tests were carried out, allowing tests to be performed with and without water stress using irrigation. However, the elevated temperatures and low relative air moisture in determined phases of the rice cycle, mainly at flowering, induced sample damage due to the emission of white panicles.

\section{CONCLUSIONS}

Spikelet sterility was the trait with the highest correlations with productivity in both the conditions with and without stress, followed by grain weight.

The contact surface of the root in the soil was the trait that had the highest positive direct effect on grain yield in drought stress conditions.

RESUMO: O objetivo desse trabalho foi estimar as correlações fenotípicas entre 14 características obtidas em uma coleção nuclear temática de arroz de terras altas para tolerância à seca e desdobrá-las em seus efeitos diretos e indiretos por meio da análise de trilha. Foram conduzidos dois experimentos (com e sem estresse hídrico). Avaliou-se 100 materiais no delineamento experimental em látice triplo 10x10. A parcela foi formada por quatro linhas de 3,0 metros de comprimento espaçadas de 0,35 metros. A área útil da parcela foi constituída pelas duas linhas centrais de 2,0 metros de comprimento, perfazendo $1,4 \mathrm{~m}^{2}$ de onde foram coletados dados de 14 características sendo, cinco do sistema radicular e nove da parte aérea da planta. Das características avaliadas, esterilidade das espiguetas foi a principal determinante da produtividade de grãos apresentando correlação negativa de elevada magnitude de $-0,78$ e $-0,59$ nos ambientes com e sem estresse de seca, respectivamente. No desdobramento das correlações esterilidade das espiguetas apresentou efeitos diretos negativos na produtividade de grãos nos ambientes com $(-0,60)$ e sem $(-0,62)$ estresse hídrico, corroborando as correlações negativas entre estas características. Os dados obtidos enfatizaram que a esterilidade das espiguetas é uma variável importante para a seleção de linhagens de arroz submetidas à deficiência de água. Os coeficientes de determinações parciais indicaram que apenas $70,33 \%$ no ambiente com estresse e 50,30\% no ambiente sem estresse da variação da produtividade de grãos foram explicados, fenotipicamente, pelas variáveis consideradas na análise de trilha evidenciando a complexidade da seleção para tolerância à seca em arroz.

PALAVRAS-CHAVE: Arroz de terras altas. Caracteres. Raiz. Tolerância à seca.

\section{REFERENCES}

ABADIE, T.; CORDEIRO, C. M. T.; FONSECA, J. R.; ALVES, R. B. N.; BURLE, M. L.; BRONDANI, C.; RANGEL, P. H. N.; CASTRO, E. M.; SILVA, H. T.; FREIRE, M. S.; ZIMMERMANN, F. J. P.; MAGALHÃES J. R. Construção de uma coleção nuclear de arroz para o Brasil. Pesquisa Agropecuária Brasileira, v. 40, pp. 129-136, 2005. DOI: 10.1590/S0100-204X2005000200005. https://doi.org/10.1590/S0100-204X2005000200005

ABREU, H. K. A.; TEODORO, P. E; PANTALEÃO, A. A.; CORREA, A. M. Genetic parameters, correlations and path analysis in upland rice genotypes. Bioscience Journal, Uberlândia, v. 32, n. 2, pp. 354-360, 2016. https://doi.org/10.14393/BJ-v32n2a2016-29308

ALVAREZ, R. de C. F.; CRUSCIOL, C. A. C.; NASCENTE, A. S.; RODRIGUES, J. D.; HABERMANN, G. Gas exchange rates, plant height, yield components, and productivity of upland rice as affected by plant regulators. Pesquisa Agropecuária Brasileira, v. 47, pp. 1455-1461, 2012. DOI: $10.1590 / \mathrm{S} 0100 \square 204 \mathrm{X} 2012001000007$. 
BABU, R. C.; NGUYEN, B. D.; CHAMARERK, V.; SHANMUGASUNDARAM, P.; CHEZHIAN, P.; JEYAPRAKASH, P.; GANESH, S. K.; PALCHAMY, A.; SADASIVAM, S.; SARKARUNG, S.; WADE, L. J.; NGUYEN, H. T. Genetic analysis of drought resistance in rice by molecular markers: Association between secondary traits and field performance. Crop Science, v. 43, pp. 1457-1469, 2003.

https://doi.org/10.2135/cropsci2003.1457

BOTA, J.; MEDRANO, H.; FLEXAS, J. Is photosynthesis limited by decreased Rubisco activity and RuBP content under progressive water stress? New Phytologist, v. 162, pp. 671-681, 2004. DOI: 10.1111/j.14698137.2004.01056.x. https://doi.org/10.1111/j.1469-8137.2004.01056.x

CRUZ, C. D. GENES - A software package for analysis in experimental statistics and quantitative genetics. Acta Scientiarum, v. 35, pp. 271-276, 2013. DOI: 10.4025/actasciagron.v35i3.21251.

https://doi.org/10.4025/actasciagron.v35i3.21251

CRUZ, C. D.; REGAZZI, A. J.; CARNEIRO, P. C. S. Modelos biométricos aplicados ao melhoramento genético. 3rd. Ed. UFV, Viçosa, 2004, 480p.

HUANG, Y.; XIAO, B.; XIONG, L. Characterization of a stress responsive proteinase inhibitor gene with positive effect in improving drought resistance in rice. Planta, v.226, pp.73-85. 2007. DOI: 10.1007/s00425006-0469-8. https://doi.org/10.1007/s00425-006-0469-8

INSTITUTO NACIONAL DE METEOROLOGIA (INMET). Monitoramento das estações automáticas: Gurupi - TO. 2008. Disponível em: <http://www.inmet.gov.br/sonabra/maps/automaticas.php>. Acesso em: 15 jul. 2008.

JAGADISH, S. V. K.; CRAUFURD, P. Q.; WHEELER, T. R. High temperature stress and spikelet fertility in rice (Oryza sativa L.). Journal of Experimental Botany, v. 58, pp. 1627-1635, 2007. DOI:

10.1093/jxb/erm003. https://doi.org/10.1093/jxb/erm003

JONGDEE, B.; PANTUWAN, G.; FUKAI, S.; FISCHER, K. Improving drought tolerance in rainfed lowland rice: An example from Thailand. Agricultural Water Management, v. 80, pp. 225-240, 2006.

https://doi.org/10.1016/j.agwat.2005.07.015

KEMPTHORNE, O. An introduction to genetic statistics. The Iowa State University Press, Ames, 1973.

KUMAR, A.; BERNIER, J.; VERULKAR, S.; LAFITTE, H. R.; ATLIN, G. N. Breeding for drought tolerance: Direct selection for yield, response to selection and use of drought-tolerant donors in upland and lowlandadapted populations. Field Crops Research, v. 107, pp. 221-231, 2008. DOI:10.1016/j.bbr.2011.03.031. https://doi.org/10.1016/j.bbr.2011.03.031

KUREK, A. J.; CARVALHO, F. I. F.; ASSMANN, I. C.; MARCHIORO, V. S.; CRUZ, P. J. Análise de trilha como critério de seleção indireta para rendimento de grãos em feijão. Revista Brasileira de Agrociência, v.7, pp.29-32, 2001.

LAFITTE, R.; BLUM, A.; ATLIN, G. Using secondary traits to help identify drought-tolerant genotypes. In: FISCHER, K. S.; LAFITTE, R.; FUKAI, S.; ATLIN, G.; HARDY, B. (eds) Breeding rice for drought-prone environments. IRRI, Los Baños, 2003, pp.37-48.

MARCHEZAN, E.; MARTIN, T. N.; DOS SANTOS, F. M.; CAMARGO, E. R. Análise de coeficiente de trilha para os componentes de produção em arroz. Ciência Rural, v. 35, pp. 1027-1033, 2005. DOI:

10.1590/S0103-84782005000500007. https://doi.org/10.1590/S0103-84782005000500007

MATHER, W. B. Principles of quantitative genetics. Burgess Publishing Company, Minneapolis, 1966. 
MODE, J. C.; ROBINSON, H. F. Pleiotropism and the genetic variance and covariance. Biometrics, v. 15, pp. 518-537, 1959. https://doi.org/10.2307/2527650

NGUYEN, H. T.; BABU, R. C.; BLUM, A. Breeding for drought resistance in rice: Physiology and molecular genetics considerations. Crop Science, v. 37, pp. 1426-1437, 1997.

https://doi.org/10.2135/cropsci1997.0011183X003700050002x

SHINOZAKI, K.; YAMAGUCHI-SHINOZAKI, K. Gene networks involved in drought stress response and tolerance. Journal of Experimental Botany, v. 58, pp. 221-227, 2007. DOI:10.1093/jxb/erl164.

https://doi.org/10.1093/jxb/erl164

STONE, L. F.; MOREIRA, J. A. A.; SILVA, S. C. Tensão da água no solo e produtividade do arroz.

Circular Técnico 19, Embrapa - Cnpaf, Goiânia, 1986.

TERRA, T. G. R.; LEAL, T. C. A. B.; RANGEL, P. H. N.; OLIVEIRA, A. B. Características de tolerância à seca em genótipos de uma coleção nuclear de arroz de terras altas. Pesquisa Agropecuária Brasileira, v. 50, pp. 788-796, 2015. DOI: 10.1590/S0100-204X2015000900007. https://doi.org/10.1590/S0100-

204X2015000900007 